\title{
REINADO DE HORROR: TORTURA NA AMAZÔNIA DURANTE O CICLO DA BORRACHA
}

\author{
Leopoldo M. Bernucci \\ University of California at Davis - USA
}

\section{RESUMO}

Este trabalho examina a prática da tortura no oeste da Amazônia, no período 1900-1920, em áreas que cobrem atualmente os territórios do Peru, Colômbia e Brasil. Um dos métodos mais comuns de tortura foi a flagelação, prática que ali foi empregada não só para punir, mas também intimidar e escravizar os ameríndios que ocupavam, principalmente, as zonas entre os rios Putumayo/Içá e Caquetá/Japurá. Discutem-se aqui o contexto socioeconômico e a época do ciclo da borracha em que essa prática cruel e sádica se tornou frequente e sofisticada quanto aos vários métodos de castigo e extermínio. As principais ações criminais envolvendo a tortura ocorreram durante a época do monopólio da Peruvian Amazon Rubber Company, firma responsável pelo comércio da extração, do fabrico e da venda da borracha no mercado internacional. O presente ensaio explora os aspectos culturais e históricos da flagelação, como método que também tem sido empregado em ritos de passagem em muitas comunidades indígenas. Por fim, este ensaio problematiza um possível ponto de convergência entre as duas práticas de flagelação, uma com intenção punitiva e a outra com finalidade ritualística.

PALAVRAS-CHAVE: Tortura. Amazônia. Indígenas. Then Peruvian Amazon Rubber Company. Ciclo da Borracha

Em um ensaio já bastante conhecido, "Cultura do Terror - Espaço da Morte. O Relatório sobre o Putumayo de Roger Casement e a Explicação da Tortura", o antropólogo australiano Michael Taussig faz a seguinte observação:

Apesar de o grau de crueldade ser imenso e inquestionável, a maior parte das provas desse tipo de crime chega até nós somente através de narrativas. Para um historiador rigoroso isso seria um desafio, já que ele teria que separar o que é verdadeiro daquilo que foi exagerado ou atenuado (TAUSSIG, 1984, p. 482). ${ }^{1}$

É moeda corrente e talvez universal admitir que, no sistema le-

1 Todas as traduções do inglês e do espanhol de obras aqui citadas são minhas. 
gal, o conceito do que é verdadeiro não é aceito sem evidências. A prova de um crime se baseia nos achados da investigação. O exame de corpo de delito é o exame sob o aspecto de sua corporação física. "Desta forma", por exemplo, em linguagem jurídica, "o corpo de delito constitui-se no elemento principal de um local de crime, em torno do qual gravitam os vestígios e para o qual convergem as evidências. É o elemento desencadeador da perícia e o motivo e a razão última de sua implementação". ${ }^{2}$ Isto para as necessidades da Lei. E para as necessidades dos homens? Se para aquela é fundamental obedecer aos procedimentos e seguir a ordem cronológica dos fatos, em viva atenção aos princípios que determinam a causa e o efeito lógico das coisas, para estes, é imprescindível desafogar-se do ódio e pedir justiça ou vingança, o que de certa maneira traduz comumente os sentimentos desordenados de quem sofre e procura recobrar na memória, sempre de modo imperfeito é claro, o espaço onde os fragmentos do visto, vivido, sentido ou ouvido se congregam.

Como não sou jurista, nem teórico do direito, abordarei neste ensaio os modos narrativos de transmitir a experiência do ser torturado. Interessa-me também analisar a eficácia ou o fracasso dessas formas narrativas, conquanto quem denuncia espera ao menos obter justiça. Por isso, importa, sobretudo, debruçarmos sobre a noção de verdade, vista da perspectiva da coerência da estória que se conta e da retórica empregada e menos quando discutida a partir do sistema de leis. Mas devemos convir que é difícil, senão impossível, dissociar o modo jurídico de examinar essa experiência do modo analítico que as teorias narratológicas exigem. A intenção do presente trabalho é também tentar articular algumas ideias que possam servir para uma fértil reflexão em torno do fenômeno da tortura numa área geograficamente bem delimitada e num momento histórico devidamente estabelecido.

2 Consultar: http://www.jusbrasil.com.br/topicos/291084/corpo-de-delito 
Para isso, é mister, primeiramente, repassar alguns dados históricos e depois voltarmos ao exame das formas de narrar as torturas cometidas na Amazônia.

O período que estaremos abordando no presente estudo vai de 1900 a 1920, um espaço de tempo que pode parecer curto, mas que se vê alongado pela intensidade dos fatos históricos que serão discutidos. Tal período marca as primeiras acusações massivas de tortura, escravidão e extermínio nos seringais da região dos rios Caquetá e Putumayo do lado colombiano ou, do lado brasileiro, dos rios Japurá e Içá, respectivamente. ${ }^{3}$ Essas acusações, que já se haviam tornado públicas em jornais de Manaus, como o Jornal do Commercio, em princípios do século XX, caíram depois no olvido ou na indiferença das autoridades locais, até que um jornalista e editor de dois jornais bimensais de Iquitos, La Sanción y La Felpa, resolveu denunciar os fatos. O corajoso jornalista, Benjamín Saldaña Rocca, recolhendo testemunhos juramentados de vítimas e pessoas que haviam trabalhado nos seringais do poderoso barão da borracha Julio César Arana, fê-los publicar não só nos seus periódicos, mas também em El Comercio e La Prensa de Lima e na revista inglesa Truth. Estas denúncias foram o estopim de outras futuras e graves acusações e, na verdade, um dos fatores que também contribuiu mais tarde para a derrocada do império da Casa Arana.

Julio César Arana era um cidadão peruano, que de vendedor de chapéus Panamá em Yurimaguas, às margens do Huallaga, Peru, passou a ser um dos maiores empresários da Amazônia do seu tempo, e acionista majoritário da The Peruvian Amazon Rubber Company, casa formada em dezembro de 1908 a partir de outras razões sociais e de sociedades que envolveram membros de sua própria família. Homem

3 Segundo o Padre Gaspar de Pinell há uma distância de 21 km entre um rio e outro, no lado colombiano. 
altamente familiarizado com a vida e o comércio dos seringais amazônicos desde 1881, inclusive os do atual território do Acre, com seu escritório central em Iquitos e uma sucursal em Manaus que funcionou de 1903 a 1914, Arana comercializou a borracha internacionalmente vendendo-a com lucros astronômicos aos principais portos da Amazônia da época - Manaus, Belém e Iquitos - para daí ser distribuída ao mercado estrangeiro, principalmente ao da Inglaterra.

Estima-se que nas duas grandes áreas de seringais apropriadas por Arana na região do Caquetá e do Putumayo, conhecidas como La Chorrera e - ironicamente - El Encanto, mais de trinta mil indivíduos, principalmente índios huitoto, bora, andoque e ocaina, foram abusados, torturados e assassinados nessa região. Esses indivíduos, a maioria homens adultos, mas também mulheres e crianças, depois de caçados, eram forçados a trabalhar de forma desumana nos diversos seringais controlados por Arana. Invariavelmente,

[os] índios [tinham] que entregar 14 quilos de borracha a cada dez dias, sem que [faltasse] um só grama; do contrário, eles [eram] suspensos pelos quatro membros e [...] severamente flagelados a ponto de ficarem meio-mortos. Depois seus corpos lacerados [eram] lavados com salmoura e pimenta. Este é o remédio que eles [recebiam] (OLARTE CAMACHO, 1910, p. 59).

Historicamente, a modalidade de tortura empregada de forma mais comum e disseminada por toda a Amazônia, não só a brasileira, era o flagelo, executado com a vítima presa por correntes ao instrumento de tortura. Este método consistia em atar as mãos e os pés do índio e dar-lhe de 60 a 100 açoites com um chicote de couro de anta até que a parte afetada perdesse a pele. A vítima nessa altura, dependendo da idade e do preparo físico, podia já estar inconsciente ou até lúcida, mas agonizando de modo brutal. Ou ainda de uma viga de um barracão, pendurava-se com uma corda o condenado há dois palmos do rés-do-chão e ali se passava a açoitá-lo até ele ficar prostrado ou 
inconsciente. Cortava-se a amarra que ligava os punhos dele e este, ao despencar no chão, infalivelmente fraturava alguma parte do corpo. Muitas vezes o indivíduo que sangrava, e não era tratado imediatamente, "bichava" e o tecido do seu corpo entrava em franco e rápido estado de putrefação levando-o, em menos de dois dias, à morte. ${ }^{4}$

Walter. E. Hardenburg, engenheiro-civil norte-americano que esteve nessa época na região, descrevendo essa prática grotesca, ilustra -a com dois incidentes:

Eu fui informado por um indivíduo de Barbados, que muitas vezes desempenhou o papel de feitor desses açoites, que ele tinha visto mães serem flageladas, por culpa da pouca borracha trazida pelos seus filhos. Os meninos eram muito pequenos para serem castigados, e sendo assim, diante da mãe sendo açoitada "com apenas algumas chicotadas" para fazê-lo um melhor trabalhador, o menino assistia horrorizado e chorando a essa cena. Homens e mulheres eram suspensos pelos braços, torcidos muitas vezes e atados pelos punhos por trás das costas, e em posição agonizante, com seus pés elevados do chão, eles eram flagelados nas nádegas e nas pernas. O instrumento empregado era invariavelmente um chicote torcido, ou de várias camadas de couro de anta costuradas, um couro não tão grosso como o de hipopótamo que eu vi na África para flagelar, mas obviamente suficiente como para cortar o corpo humano em pedaços. [...] [Em um dos seringais, em 1910, os índios já não eram açoitados com chicote de couro de anta mas sim] com golpes de facão. [...] Os golpes recebidos por este instrumento nas espáduas ou nas costas deveriam ser excessivamente dolorosos, mas possivelmente não deixavam nenhuma cicatriz permanente ou sinais (HARDENBURG, 1912, p. 306).

Este reino de terror chega a seu ápice e de forma tão generalizada na década de 1910, mas logicamente o regime de escravidão e a implantação dos métodos de coerção e tortura não são tão recentes. Datam do começo da colonização espanhola e portuguesa, como adverte Casement:

4 Select Committee on Putumayo, p. 479. Ver também CORNELIO HISPANO, p. 267. 
O terror que o índio tinha pelo chicote ficou claro entre os membros do grupo de Pizarro durante os primeiros contatos que eles tiveram com a populações indígenas dos Andes, já que ao lermos os documentos legais espanhóis, o vice-rei, Dom Francisco de Toledo, que foi ao Peru em 1569 e saiu de lá em 1581, entre outras leis para civilizar os remanescentes do povo incaico, prescrevia que "qualquer índio que fizer amizade com uma índia que seja infiel $l^{5}$ deverá receber 100 açoites para a primeira ofensa, sendo este o castigo que eles mais odeiam" (SLAVERY IN PERU, 1913, p. 261)

Frei Samuel Fritz, que viajou pelo Amazonas entre 1686 e 1723, relata que em 1701, ao chegar na Missão de São Paulo, foi surpreendido por um motim dos ticuna e omagua. Os rebeldes foram presos e flagelados pelos soldados portugueses (FRITZ, 1922, p. 110). Outro testemunho dos horrores cometidos em território amazônico data de 1838, do coronel A. Codazzi e registrado pelo escritor venezuelano Francisco Michelea y Rojas que percorreu extenso território até chegar ao Brasil. Suas observações nos dão um vivo quadro de como os coronéis e abastados fazendeiros exploravam a população indígena:

[...] chegou a tanto a impudência desses homens, que tão logo morre um pai de família, se lhes extraem os filhos menores sob o especioso pretexto de que são órfãos, e que a mãe não é mulher honesta, ou incapaz de mantê-los: se é esta que morre sucede o mesmo, e então o pai é tachado de bêbado, dissoluto e preguiçoso. Enfim, se ambos morrem, já não é necessário ter irmãos, parentes próximos e honrados, são de exclusiva propriedade do político, o qual os reparte como ele bem quiser, sem descuidar-se de si próprio [é claro]. Assim, em cada casa destes magnatas, há 5 ou 6 indiazinhas, e outros tantos índios que não recebem nada, exceto comida muito ruim, o chicote e uma roupa miserável. Tomara que este relatório possa beneficiar os 2.000 infelizes que trabalham sem cessar para enriquecer a 15 egoístas. Cayeara, 14 de março de 1838 (MICHELONA Y ROJAS, 1867, p. 332).

Por outro lado, o tenente da marinha norte-americana William Lewis Herndon, percorrendo a Amazônia de Iquitos até Belém em me5 Não catequizada. 
ados do século XIX, constatou que muitas vezes alguns padres missionários eram o equivalente dos coronéis e governadores dessas regiões: "A maneira de governar é paternalista. Os índios reconhecem no padre o poder de nomear e demitir curacas, capitães [chefes indígenas], e outras autoridades, de usar o chicote e confiná-los no cepo." Um peruano descendente de espanhóis que serviu de intérprete a Herndon dizia que "para governar os índios, nada melhor do que o santo palo [...]" (HERDON, 2000, p. 213). ${ }^{6}$

As primeiras denúncias de Saldanã Rocca em 1907 deram início a uma série de acusações, como as de Hardenburg publicadas pela revista inglesa Truth e no seu livro The Putumayo - The Devil's Paradise (1912) e em quatro outros livros: Las crueldades en el Putumayo $y$ en el Caquetá (1910) de Vicente Olarte Camacho; The Putumayo Red Book (1912), editado por Norman Thomson; The Lords of the Devil's Paradise (1913), de Sidney Paternoster; e o extenso relatório intitulado El proceso del Putumayo - sus secretos inauditos (1915), do juiz Carlos A.Valcárcel. Em 1913, publica-se ainda o Slavery in Peru, pelo Congresso norte-americano. Como complemento dessa documentação, Sir Roger Casement deixou preciosas anotações no seu relatório inserido no "Blue Book" (1912), do governo britânico. Este relatório foi o documento que mais despertou a atenção das autoridades inglesas, posto que a Casa Arana empregava, também, cerca de trinta e cinco barbadenses implicados nos abusos e crimes cometidos e que foram interrogados in loco pelo cônsul britânico Casement em 6 No seu livro Memorandum de viaje (1905), Joaquín Rocha também narra um episódio parecido e reproduz a ordem de Miguel Velasco, Corrigidor de Santa Rosa, ao Comissário de Praça de Descanse: "Segue para esse lugar os Reverendos Padres Missionários. Peço-lhe que coloque gente para reparar o caminho até Chaupiplaya, limpar a praça, abrir as ruas e arrumar o Convento. Aquele que não obedecer, agarre-o pelo pescoço, leve-o à cadeia e coloque-o a alvejar o tronco (o cepo), e que peça misericórdia. E se o senhor não o fizer, logo depois de ter recebido esta nota eu irei, e prepare as varas porque o pau vai comer. Que Deus o guarde" (p. 21). 
julho de 1912. Em 6 de novembro deste mesmo ano, a Câmara dos Comuns da Inglaterra instalou uma comissão de investigação dos atos cometidos no Putumayo e essa documentação ficou conhecida como "Report and Special Report of the Select Committee on the Putumayo" (White Paper no. 148, 1913).

Todas essas publicações, sem dúvida, serviram para conscientizar grupos de leitores, tanto na Europa como nas Américas, que desconheciam completamente o quadro de horror que as mãos sujas dos seringalistas da Casa Arana haviam pintado na Amazônia. Não tinham bastado os diversos artigos de denúncia em jornais da região, nem mesmo o brado de Euclides da Cunha que já em 1904, portanto antecipando-se em pelo menos três anos a todos os demais autores aqui mencionados, publicara dois poderosos ensaios titulados "Conflito inevitável" e "Contra os caucheiros". ${ }^{7}$ Do ponto de vista literário, é preciso mencionar também o livro de Alberto Rangel, publicado em 1908, Inferno verde, obra singularíssima de denúncia social, na qual o autor desmascara o suposto êxito do sistema governamental de emigração de nordestinos, principalmente os cearenses, para a Amazônia.

Casement, que já realizara uma investigação sobre os horrores no Congo belga de Leopoldo II em 1903, a qual ele relatou no "White Book", era a pessoa mais indicada para trabalho semelhante na floresta amazônica. Nomeado cônsul em Belém, ficou ali de março a novembro de 1907, antes de ser transferido para o Rio de Janeiro. Em 1910, vamos encontrá-lo de volta na Inglaterra e nesse mesmo ano, depois de ser comissionado a uma segunda investigação sobre o regime de terror na Amazônia, ele chegará a Iquitos com um grupo de investigadores britânicos sob a sua direção em 31 de agosto. Ler o relatório

7 Ver Contrastes e confrontos. Inicialmente publicados em O Estado de S. Paulo de 14/5/1904 e 22/5/1904, respectivamente. In: Obra completa, vol. I (ed. 1966), p. 155-159 e 159-162. 
de Casement e as notas de seu diário hoje em dia é uma experiência única em que a indignação se mistura à impotência. Como é possível que em nome do ideal civilizatório, perguntava ele, a Inglaterra pôde deixar que esse regime de escravidão, abusos e crimes se instalasse nas zonas do Caquetá e Putumayo?

Mas Casement não foi a única testemunha ocular autorizada. Outro indivíduo, o capitão Thomas William Whiffen, autor do North-West Amazon (1915), pôde constatar em 1908-1909, período em que viveu nessa região, que toda vez que ele visitava o território da The Peruvian Amazon Rubber Company, essa empresa enviava para acompanhá-lo um membro influente dela, para "ocultar todas as atrocidades cometidas e também as que estavam acontecendo naquele momento; em outras palavras, quando [ele] chegava num seringal os instrumentos de tortura eram escondidos, os prisioneiros liberados, etc; e não foi senão até a [sua] segunda visita, depois de descobrir que esses instrumentos estavam escondidos no mato e alguns índios presos sob forte guarda, que [ele] se deu conta da gravidade do problema."

Casement descreve esses instrumentos, como feitos de uma tábua grossa de madeira, com 19 apertados orifícios de não mais de $71 / 2 \mathrm{~cm}$ de diâmetro por onde passava a parte inferior da perna da vítima, junto ao calcanhar que, depois de ali encaixada, ficava sentada sobre uma viga em posição que agravava a tensão entre os membros e o dorso da pessoa. Assim, a vítima era açoitada sem resistência e, muitas vezes, abandonada até morrer de fome, ou perecia logo depois do castigo como resultado das feridas que recebia (CASEMENT, 1997, p. 193).

Ao lermos sobre os horrores dos seringais dessa época, a pergunta que normalmente vem à mente é esta: como era possível que

8 Report and Special Report of the Select Committee on Putumayo, \#13012, p. 516. Este testemunho foi corroborado pelas observações de Casement nesse mesmo relatório. Ver \#788, p. 34. 
os índios não pudessem se rebelar contra tamanha crueldade? Por que eles se mantinham vítimas desse sistema sem encontrar uma saída? A pergunta é complexa e Casement procurou mais de uma vez respondê-la. O que ele chama de "fatal obediência" dos índios, um traço que Casement observou no seu caráter, tem raízes profundas na história dos povos nativos da Amazônia. Aliás, consideremos também as práticas de punição por flagelo, empregadas pelos senhores de escravos, governadores e missionários. O escritor colombiano Miguel Triana que percorreu o Putumayo na primeira década do século passado, aludindo a uma brincadeira de mau-gosto de um religioso contra um índio mocoa, conta-nos o seguinte diálogo que teve com um padre:

- Vou dar um susto naquele índio, nos disse o missionário que nos atendia.

Chamou imediatamente o irmão leigo e lhe deu esta ordem: "levem para a cadeia este índio"; o irmão leigo transmitiu a ordem ao senhor prefeito e este, pessoalmente, deu ordem de prisão ao indígena.

- A este índio, agregou o missionário, poderiam ser aplicados três açoites, segundo os costumes. O costume por aqui, e no conceito dos índios, é a única lei, como você terá ocasião de observar. Tudo se detêm entre os índios diante desta frase: "não é nosso costume." $[\ldots]$

- Mas isto de flagelar os índios é um costume ao qual eles renunciariam contentemente, por ser sempre o homem inimigo das penas dolorosas, sobretudo quando é ele a vítima de tal castigo.

- Nem tanto. O castigo por flagelo é sem dúvida um dos inveterados costumes e dos mais difíceis de desarraigar, como lhe demonstrarei: em primeiro lugar, a dor tem uma eficiência misteriosa que o defende. Tenho observado que os índios ficam tranquilos e até festivos, depois do flagelo; a vítima tem por isto obrigação de dizer depois dele: "Deus lhe pague". Se não disser assim, manda o governador que lhe deem três açoites mais, até quando o castigado perde a ira e se manifesta agradecido. Entre os índios, as chicotadas mantêm o princípio da autoridade, a docilidade de caráter $^{9}$ e a pureza de costumes: são, assim, a base dos mesmos costumes. Em segundo lugar,

9 Ênfase minha. 
são os próprios índios, como os governadores, e para conservar a constituição social não escrita que eles obedecem cegamente em suas práticas governamentais, aqueles que mantêm sempre em vigor a pena por flagelo (TRIANA, 1907, p. 312-313).

Esse diálogo reproduzido por Triana tem a força dos ácidos e nos choca profundamente. O que eu gostaria de extrair dele para efeitos de comentário são duas lições: com a primeira aprendemos que o abusado ao extremo pode chegar a ser amansado e adaptar-se ao abuso; e com a segunda lição, ainda mais perversa porque revela a sutil astúcia de quem abusa, que o código cultural do índio - aquele que lida não com as leis, porque elas são dos brancos, mas com os costumes, por estes serem do modo natural de agir dos homens, pode ser violado e monstruosamente manipulado pelo chamado "civilizado". Esta falácia cultural que resulta no aproveitamento abusivo, malicioso e desonesto dos códigos do outro em benefício do "civilizado" e em detrimento do índio, é claro, confundindo e perturbando seu modus vivendi, é o que nos interessa explorar agora. Estamos diante de um sistema em que o algoz tem quase todas as chaves para interpretar o outro: conhece a sua fatal obediência, sabe misturar, adulterar os signos ritualísticos transformando-os em signos práticos ou de utilidade para a punição. Muito diferente e mais difícil de ser combatido foi esse massacre de índios na Amazônia, daquele outro que seria mais conhecido, o horripilante genocídio cometido pelos nazistas. A diferença está em que no terrível holocausto europeu, os códigos entre verdugos e vítimas eram absolutamente compreensíveis e inteligíveis. Assim, novamente, seguindo nesta linha de investigação, o meu objetivo é ver como o "civilizado" consegue invadir e deturpar o terreno cultural do índio aproveitando de suas práticas ritualísticas, seus costumes e seu natural caráter dócil para exercer sobre ele coerções, imputar-lhe penas, adulterando, confundindo e muitas vezes destruindo o seu universo semiológico primigênio para reconfigurá-lo de outra maneira. ${ }^{10}$ Trata10 A docilidade de caráter é um traço da personalidade do índio comentado não só pelos naturalistas mas também pelos missionários. Ver Hist. de las misiones, p. 253. 
se, sobretudo, de procurar melhor entender como os códigos culturais do índio são modificados pelo "civilizado" ao longo dos anos e como estes operam depois de largo período de forma sistêmica na sua vida social. Tomemos um primeiro exemplo.

Em 1907, depois da dissolução das sociedades entre Arana e os colombianos Gregorio Calderón e Pérez em 1905, o sistema dos seringais do Putumayo e do Caquetá passou por uma relativa mudança de funcionamento.

Confusos ficaram os selvagens huitoto que, convencidos do caráter divino dos mandatários, esperavam das autoridades colombianas castigo por tanto luxo de crueldades e de crimes - como garantia de seus mais elementares direitos - quando viram os seus vitimários em conversa amigável com os que supunham ser seus divinos salvadores (OLARTE CAMACHO, 1910, p. 67).

Retenhamos para fins de nossa análise dessa deplorável situação a expressão "caráter divino dos mandatários". É duvidoso se realmente os índios pensavam que as autoridades colombianas possuíam essa qualidade sobrenatural. Todavia, é fácil de ver a atitude de irrecusável dominação pela qual passam eles quando forçosamente subjugados. Eis os testemunhos de Olarte Camacho:

O índio é tão humilde, por exemplo, que ao ver que o fiel da balança não marca dez quilos [de borracha] exatos, ele mesmo põe as mãos adiante e se joga no chão para receber o castigo. Então, o chefe ou um dos seus subalternos avança, agacha-se, toma o índio pelos cabelos, golpeia-o, levantando-lhe a cabeça e deixando-a cair do lado do rosto contra o chão, e depois de banhá-lo em sangue e de aplicarlhe uns quantos bofetões, socos e pontapés, flagelam-no" (OLARTE CAMACHO, 1910, p. 154).

Saldanã Rocca também denuncia essa triste subserviência:

Eles sabem por experiência o que o fiel da balança deve marcar, e quando ela indica que eles trouxeram a quantia que estavam obrigados a trazer, eles pulam de alegria e riem. Quando isto não acontece, eles se jogam de bruços no chão e, nesta atitude, esperam o rebenque, a bala ou o facão. $\mathrm{O}$ instrumento fica a critério do gerente 
do seringal, mas geralmente eles recebem cinquenta chicotadas até que a carne comece a desprender-se do corpo em pedaços, ou então é cortada a pedaços com facão. Este espetáculo bárbaro acontece diante de todos os presentes, inclusive suas mulheres e filhos (HARDENBURG, 1912, p. 217).

A questão sobre a qual verdadeiramente importa refletir já foi de alguma maneira colocada por Michel Foucault na década de 1970.

A história - diz ele - que nos molda e determina o que somos tem a forma muito mais de uma guerra que de uma linguagem: relações de poder e não relações de sentido. A história não tem 'sentido', embora com isso não queiramos dizer que ela seja absurda ou incoerente. Ao contrário, ela é inteligível e pode ser suscetível de análise até o mais mínimo detalhe - mas isto ocorre segundo a inteligibilidade dos conflitos, das estratégias e das táticas (FOUCAULT, 1980, p. 114).

Com os exemplos aduzidos e com as palavras de Foucault em mente devemos perguntar, por exemplo, o que significa superioridade do branco frente ao índio para se admitir que este considere aquele sobrenatural, quando estamos diante de dois modelos culturais diferentes? O que é exatamente essa docilidade que mencionamos há pouco? Estaria o religioso se baseando mais nos valores próprios de seu grupo social quanto à percepção dos fatos, que propriamente em como pensaria e sentiria o índio? Como apreender o real significado desses atos? É possível captar um só e único sentido, ou, como quer Foucault, devemos entender os sentidos sempre em conflito ou em tensão? Essa ambiguidade nos leva agora a fazer mais uma pergunta, audaciosa: como interpretar as práticas de tortura por flagelo que vimos, se pudermos admitir que nas sociedades indígenas os açoites são usados com propósitos ritualísticos, portanto deste modo incorporados na sua cultura, e não como sendo tão estranhos ou incomuns segundo o nosso modo de pensar? E ainda mais: não estaria até certo ponto a prática que causa a dor por auto-castigo inserida de maneira semelhante na vida de alguns dos missionários da Amazônia? 
Conta-nos o jesuíta Juan Rivero que o padre Rafael Ramírez enviado a uma missão da região do Orinoco no século XVII:

travava guerra contínua com seu corpo, para sujeitá-lo ao espírito; as disciplinas de ferro com que macerava seu corpo causavam um piedoso horror a quem as observava, e não menor assombro a quem ouvia os duros e desapiedados golpes com que as manejava contra si; armava-se desde as primeiras horas da manhã como soldado de Cristo que havia que entrar em batalha, de um cilício de pontas aceradas, para resistir seus inimigos; seus jejuns eram perpétuos, rara a mortificação dos seus sentidos, admirável sua vida penitente... (RIVERO, 1883, p. 189). ${ }^{11}$

Culpa e castigo, formas que a religião aperfeiçoou de modo a estabelecer o seu regime de controle sobre os fiéis, calam profundamente no ânimo desses padres e, por extensão, também no dos índios conversos que conviveram com eles. Como igualmente deveriam calar as práticas de flagelo tantas vezes comentadas pelos viajantes europeus em certas comunidades tribais para determinar um rito de passagem. A literatura é diversa, indo de Jules Creveaux, Theodor Koch-Grünberg, Russell Wallace, Hamilton Rice, Carl F. Von Martius, Thomas Whiffen, mas todas mais ou menos coincidindo nas suas descrições.12 Vejamos a de Von Martius:

A festa é para comemorar a entrada na virilidade dos rapazes. [...]

11 O mesmo autor nos da esta outra descrição do Padre Ignacio Fiol (1629- ), de Palma de Mallorca : "além dos cilícios e disciplinas com os quais macerava o seu corpo à vista de uma caveira, que entre uns ossos tinha sobre a mesa aos pés de um santo crucifixo, não dormia na sua cama, mas numa tábua sem nada no chão frio, servindo-lhe de cabeceira uma dura pedra, mesmo durante o rigor do inverno; e para que sua mortificação fosse contínua, à imitação de São Francisco de Borja, caminhava com sapatos cheios de grãos de trigo, grãos de bico e pedrinhas; seu jejum era muito frequente e quando seus pais e irmãos, em dias de Páscoa, tinham mesa esplêndida com deliciosa viandas, sua comida era só uma sardinha ou um pouco de peixe salgado, que ele mesmo assava nas brasas e comia solitário num cantinho da casa, sem que nem uns nem outros pudessem demovê-lo de tal desejo." Hist. de las misiones, p. 263.

12 CREVEAUX, p. 548; KOCH-GRÜNBERG, III, p. 315, 316, 325); WALLACE, p. 345; RICE, p. 161; SPIX e VON MARTIUS, p. 120-121, 198, 216; WHIFFEN, p. 157$158,168,198$. 
Os homens em seguida perfilam-se aos pares, de acordo com prévia escolha e flagelam-se com compridas correias de couro de anta ou de peixe-boi até correr sangue. Essa flagelação não é tida por eles como ato hostil, mas antes como prova de amor, e, segundo todas as informações que obtivemos, deve-se considerar esse excesso de transviada atitude sexual (SPIX \& MARTIUS, 1981, p. 121-22).

Bento de Figueiredo Tenreiro Aranha narra uma prática de flagelo semelhante que parece confirmar as observações de Von Martius:

Idêntico caráter tem o caapi, que é o mesmo cachiri, com regozijo de um casamento que ainda vai contrair-se ou já está contraído. [...] É por isso que no fim do cachiri, em honra a Jurupari, homens e mulheres munem-se de chicotes para reciprocamente siviciarem-se [sic], subsequentemente a um desafio de provocante amor sensual. Para que cheguem a este desvario libam primeiramente numa cuiasita o delicioso, inebriante e divinal caapi, néctar que os faz sonhar com maravilhosas, encantadoras e adoráveis criaturas que os abraça, beijam, acariciam e abrasam nas chamas de ardente, desvairado e apaixonado amor! As chicotadas, que chegam a dilacerar-lhes as carnes, são tidas por todos nesse momento do desespero de irresistível sedução da carne, como pancadinhas d'amor! (ARANHA, 1907, p. 77-78).

Whiffen, para dar mais um exemplo, corrobora essa prática do flagelo descrita pelo naturalista alemão:

Entre os Bara, depois da dança de um Jurupari, todos jovens que estão na idade da puberdade são açoitados, como sinal da sua iniciação. O instrumento de flagelo, feito de couro de anta, é sagrado. As mulheres são excluídas dessa cerimônia, e acreditam que o grito dos meninos significa a expulsão dos demônios. O rito é considerado rigorosamente privado, e se um homem ou menino contar a sua experiência será expulso da tribo (WHIFFEN, 1915, p. 157).

É impossível apreender toda a entremeada rede de sentidos que essa prática pode ter causado no índio ao longo dos anos de contatos com o branco e de mestiçagem. Sintomaticamente, contudo, as observações de Whiffen nos fazem pensar na pouca possibilidade que restava para os índios de rebelar-se contra a prática do flagelo nos 
seringais; e que eles ainda continuem vivendo nesse clima de horror, somente encontra um possível explicação neste outro comentário do viajante inglês:

Eles [os índios] aguentam uma dose suficiente de tortura, estoicamente, quando deliberadamente aplicada, mas ao sofrer outro tipo de tortura - mistério para mim - na sua ignorância sobre as causas naturais, eles imediatamente atribuem-na à feitiçaria. Possivelmente isto se deva à infeliz maneira pela qual eles se deitam para morrer, o que realmente ocorre por auto-sugestão (WHIFFEN, 1915, p. 168).

Até aqui, observamos nesse corpus de relatos de viajantes como as práticas de flagelo entre os índios podem ser apanágio dos ritos de passagem ou estar ligados a uma razão sobrenatural. Dos modos de açoite, cujos objetivos podem ser totalmente diferentes, vimos mais acima que as formas de narrar os métodos de tortura giravam em torno de relatos de testemunhas oculares e de narrações baseados em contundentes versões orais ou escritas, mas sem provas quanto ao corpo de delito. Ficou claro também que muitas das acusações não oferecem evidências: marcas ou cicatrizes no corpo, ausência do instrumento de tortura, e - surpreendentemente para uma época já moderna - a ausência de registro fotográfico eficaz que incriminasse os verdugos. ${ }^{13}$

Das muitas fotos publicadas nos jornais e revistas da Inglaterra e do Peru, nenhuma delas, à margem dos relatos escabrosos de torturas e crimes, consegue transmitir com a mesma eficácia desses textos as cenas de terror descritas pelos autores das denúncias. Euclides da Cunha, que esteve na região de seringais do Acre, onde os tentáculos da monstruosidade de Julio C. Arana também haviam chegado, nada viu que pudesse ser usado como evidência de um crime. Como os demais, ouviu histórias dessas atrocidades e de forma comovente narra no final de um outro ensaio, "Os caucheros", a seguinte cena, esta sim, captada agora pelo seu olhar inquisitivo:

13 A foto, por exemplo, de um menino com as nádegas marcadas, com o que parece ser, golpes de chicote deixam dúvidas sobre a autoria e os motivos desses golpes. 
Num dos casebres mais conservados aguardava-nos o último habitante. Piro, amauaca ou campa, não se lhe distinguia a origem. Os próprios traços da espécie humana, transmudava-lhos a aparência repulsiva: um tronco desconforme, inchado pelo impaludismo, tomando-lhe a figura toda, em pleno contraste com os braços finos e as pernas esmirradas e tolhiças como as de um feto monstruoso. Acocorado a um canto, contemplava-nos impassível. Tinha a um lado todos os seus haveres: um cacho de bananas verdes. Esta coisa indefinível que por analogia cruel sugerida pelas circunstâncias se nos figurou menos um homem que uma bola de caucho ali jogada a esmo, esquecida pelos extratores - respondeu-nos às perguntas num regougo quase extinto e numa língua de todo incompreensível. Por fim, com enorme esforço levantou um braço; estirou-o, lento, para a frente, como a indicar alguma coisa que houvesse seguido para muito longe, para além de todos aqueles matos e rios; e balbuciou, deixando-o cair pesadamente, como se tivesse erguido um grande peso: - "Amigos". Compreendia-se: amigos, companheiros, sócios dos dias agitados das safras, que tinham partido para aquelas bandas, abandonando-o ali, na solidão absoluta. Das palavras castelhanas que aprendera restava-lhe aquela única; e o desventurado murmurando-a como um tocante gesto de saudade, fulminava sem o saber - com um sarcasmo pungentíssimo - os desmandados aventureiros que àquela hora prosseguiam na faina devastadora: abrindo a tiros de carabinas e a golpes de machetes novas veredas a seus itinerários revoltos, e desvendando outras paragens ignoradas, onde deixariam, como ali haviam deixado, no desabamento dos casebres ou na figura lastimável do aborígene sacrificado, os únicos frutos de suas lides tumultuárias, de construtores de ruínas... (CUNHA, 1966, p. 262-263).

A cena, tal como aparece, contextualizada no mundo trágico dos seringais, é de significado ambíguo. É um painel que vem a desfecho para coroar a dor pungente que o quadro mais amplo da vida dos seringueiros provoca no leitor. É um trabalho de artista que só um escritor como Euclides saberia esculpir. O seu sentido ambíguo está na impossibilidade de nós verificarmos se esse índio de identidade perdida, essa "coisa", é uma vítima direta ou não do sistema desumano criado pelos seringalistas. Terrível seria pensar que sim o é, mas também não 
menos perturbador seria interpretá-la como um ato de pura e simples crueldade e não como uma razão natural para que o índio já doente e impossibilitado de ajudar a sua comunidade fosse abandonado pelos companheiros em benefício dos demais. Esta razão natural e suas consequências parecem justificar um dos costumes indígenas que toca fundo na nossa sensibilidade moderna, mas que era praticado de modo absolutamente convencional em tempos passados segundo Whiffen:

Quando ocorre um surto de doença contagiosa na tribo, os afetados são imediatamente abandonados, até mesmo pelos seus parentes mais chegados, a casa é abandonada, e possivelmente até queimada. [...] Talvez a maneira cruel como o doente é tratado tenha a ver com o fato de que toda doença é vista como ato do inimigo que se utiliza desse meio para destruir toda uma tribo. [...] Sob todos os sentidos, está claro que a sobrevivência do mais forte é a verdadeira e severa regra da vidas das florestas na Amazônia. Do nascimento até a morte ela governa a vida e a filosofia do índio. Ajudar a preservar o menos forte significaria muitas vezes diminuir as chances de vida do mais forte. [...] Em alguns casos uma doença crônica não gera a simpatia dos demais índios. Um indivíduo que não pode caçar ou lutar é visto como inútil, meramente um fardo para a comunidade. [...] os velhos não são mortos, mas deixados ao abandono até a morte (WHIFFEN, 1915, p. 169-170).

Como Euclides, Hardenburg, Whiffen e depois Casement, mesmo também estando no Putumayo e no Caquetá, -- não viram "nada". Porém, eu diria, ouviram e sentiram tudo. E o que é o ver nada quando sabemos que para alguns desses observadores, a cena do crime foi modificada, arrumada, preparada de antemão, maquiada para apagar as provas e borrar os rastros? Recordemos que Saldaña Rocca, Olarte Camacho, Valcárcel, Rómulo Paredes, embora fortes vozes contra esses crimes, também nunca conseguiram apresentar sequer uma testemunha concreta aos tribunais ou uma foto que impactasse os juízes.

Aliás, fotos naquela época tinham a eficácia das provas de DNA de hoje em dia. Todavia, infelizmente, nem de Euclides, Casement, Whiffen, Hardenburg ou Eugène Robuchon, o geógrafo e fotógrafo da 
Société Géographique (Paris) que esteve na região em 1904-1906, e que depois misteriosamente desapareceu, pôde-se preservar as fotos tiradas por eles; e que poderiam comprometer os algozes, exceto uma, não publicada na época, mas cujo cartoon aparece no jornal $\mathrm{La} \mathrm{Fel-}$ $p a .{ }^{14}$ Tal era a importância dada à fotografia como arte mimetizadora da realidade e a maneira como as fotos eram tratadas em termos de evidência, que os responsáveis pelos massacres dos grupos indígenas se tornaram apreensivos e começaram a se "interessar" por elas; mas de um modo que demonstrava o temor de que elas pudessem ser as provas dos crimes de que todos falavam, mas que nenhum dos acusadores via. Quer dizer, as testemunhas de Casement, por exemplo, eram os barbadenses, um grupo de afrodescendentes que trabalhou para a The Peruvian Amazon Rubber Company na qualidade de capatazes. Ora, esses indivíduos ("muchachos"), embora se sentissem explorados pela Casa Arana, como confessaram a Casement, foram também utilizados para intimidar, abusar e castigar os índios. Portanto, a veracidade do testemunho dos barbadenses e, por conseguinte, a sua credibilidade estava de alguma forma prejudicada.

Na defesa que Pablo Zumaeta, gerente da The Peruvian Amazon Rubber Company, fez em 1913 contra as acusações de Roger Casement, encontramos o seguinte:

Agora, passando à fotografia que exibiu o sr. Casement e que garante ser de uma mulher condenada a morrer de fome, é outra invenção infeliz, porque ele não percebeu que no pé da rede ainda há bananas e víveres que consomem os índios e, além disso, é coisa muito natural encontrar essa gente isolada de lugares em que possa receber algum auxílio, alguns que, por falta de assistência, falecem no mais completo abandono. E por que estranhar isso, se na humanitária Inglaterra morrem de fome tantas pessoas, sem que ninguém lhe ocorra nunca culpar a alguém por essas mortes? (ZUMAETA, 1913, p. 53)

14 Cornelio Hispano diz que viu outras fotos de Robuchon. Ver De París al Amazonas, p. $272-273$. 


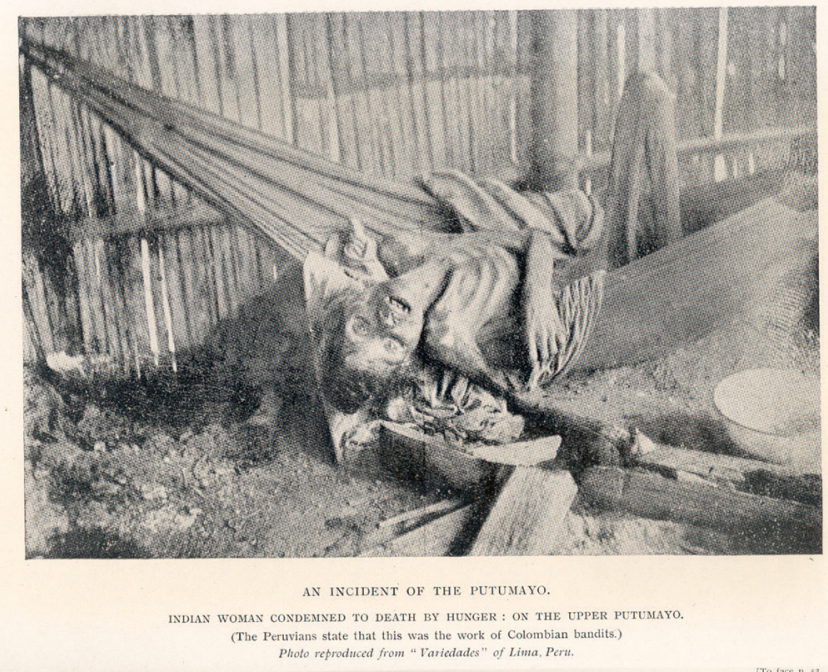

A explicação sobre essa foto evidencia uma espantosa coincidência entre ela e a descrição do índio solitário, esperando a morte, que realiza Euclides no seu ensaio "Os caucheros", como acabamos de ver. Dois indivíduos abandonados à míngua e algumas bananas para o seu suposto sustento. Mas o culpado, talvez não desta tragédia especificamente, mas de outras não se furta da oportunidade de replicar a Casement. Novamente, é Zumaeta, que pondo à prova a credibilidade daquele, faz a defesa:

apesar de seus conhecimentos de fotografia (?), [Casement] não poderá de forma alguma enriquecer a coleção de vistas e fotografias tomadas por ele mesmo no Putumayo, com uma que represente o que [representam] as que formam parte de uma página do periódico ilustrado Los Sucesos de 2 de julho de 1910, publicado em Madrid, e que, com suas respectivas fotogravuras, reproduzo (Anexo no. 8) (ZUMAETA, 1913, p. 55).

Igualmente, com argumento de sábio em voz de vilão, Julio C. Arana reforça esse álibi fazendo mais uma observação irrefutável: "as fotografias reproduzidas no livro [de Hardenburg] seriam o melhor 
desmentido às afirmações do texto, porque os grupos de índios que nelas figuram são de aspecto saudável, robusto e até expressam alegria e satisfação" (ARANA, 1913, p. 41).

E remontando outro raciocínio lógico contra a acusação de extermínio de indígenas, acrescenta:

Se alguma coisa vale ou significa a região do Putumayo, é por sua população indígena: suprimindo o índio, aquela região deixaria imediatamente de ser explorável e explorada, porque, ainda que com salários baixos que o índio aceita, a borracha extraída dessa região não teria quase nenhuma utilidade... (ARANA, 1913, p. 52).

Não é este o lugar para expandirmos as considerações sobre a fotografia como meio de documentação dos crimes na região do $\mathrm{Pu}-$ tumayo. Porém, basta somente folhear o livro En el Putumayo y sus afluentes (1907), supostamente de E. Robuchon, para dar-nos conta de que a seleção das fotos e do texto foram extremamente manipuladas pelo execrável cônsul peruano em Manaus, Carlos Rey de Castro, editor desse livro. Da mesma forma nos desviaríamos do tema principal se quiséssemos aprofundar o sentido que a retórica dos responsáveis pelos crimes teve quando se buscou justiça nos tribunais. Para esta retórica, o canibalismo como ritual praticado por algumas comunidades indígenas foi, entretanto, negativamente resignificado e deturpado com propósitos a denegrir e ultrajar esses nativos amazônicos.

Antes de concluir, retornemos ao tema central deste ensaio: a questão de como ler e interpretar as tantas acusações de tortura e genocídio na Amazônia, as quais, apesar de terem sido frequentes e volumosas, ${ }^{15}$ lamentável e escandalosamente, não serviram para incriminar a ninguém. Julio C. Arana, por exemplo, que já fora prefeito em Iqui-

15 É espantoso constatar que J. C. Arana não nega os casos de flagelo quando lhe perguntam: "O sr. acredita que eles os [crimes] cometeram? -Sim, antes eles o fizeram. O sr. acredita que no passado mulheres foram queimadas, mutiladas e torturadas pelos agentes da companhia? -Eu não acredito que elas foram mutiladas, mas penso que houve alguns casos de flagelo e assassinato". Select Committee on Putumayo, p. 493. 
tos na década de 1910, tornou-se senador do estado (departamento) de Loreto em 1921 e, em 1930, abandona a vida política para desfrutar o final dos seus dias e morrer aos 88 anos como um "bondoso" velhinho; Pablo Zumaeta, cunhado de Arana e Chefe da Companhia em Iquitos, foi eleito prefeito desta mesma cidade em 1914.

De modo anticlimático e sem justiça poética, mais um capítulo da história dos povos amazônicos terminaria de forma pateticamente trágica e sem punição para os algozes. Acresce-se a este final funesto o fato de que no dia 3 de agosto de 1916, depois de ter sido acusado de traidor, homossexual, sodomita e despojado de seus títulos honoríficos, Sir Roger Casement, defensor incansável dos povos da África e da América do Sul, foi humilhantemente destituído de todos os seus galardões e enforcado. "A sua morte, há quase um século, foi um meio conveniente para que o governo peruano reivindicasse Arana e para que o Departamento de Assuntos Estrangeiros norte-americano não prosseguisse mais com o caso". ${ }^{16}$

\title{
REIGN OF HORROR: TORTURE IN THE AMAZON DURING THE CYCLE OF THE RUBBER
}

\begin{abstract}
This paper examines rampant torture practiced in West Amazonia during the 1900s-1920s in areas that cover Peru, Colombia, and Brazil today. Flogging, one of the most common methods of torture, was used not only to punish but also to intimidate and enslave the Amerindians, mainly in the areas of the Putumayo/Içá and Caquetá/Japurá rivers. The discussion here takes place in the socio-economic context of the Rubber boom period, when the cruel and sadistic practices of torture became more frequent and sophisticated, regarding the various modes of punishment and killing. The main criminal actions involving torture took place under the monopoly of The Peruvian Amazon Rubber Company, which in those years controlled the extraction, processing, and sales of rubber in international markets. The present essay explores the cultural and historical aspects of flogging, a method that has also been employed in rites of passage in many indigenous

16 Adrew Gray em REY DE CASTRO, p. 46.
\end{abstract}


communities. This paper seeks to problematize a possible point of intersection between two flogging practices, one with a distinctive punitive objective and the other with a ritualistic purpose.

KEYWORDS: Torture. Amazonia. Indigenous people. The Peruvian Amazon Rubber Company. Rubber boom.

\section{REFERÊNCIAS}

ARANA, J. C. Las cuestiones del Putumayo. Folleto 3. Barcelona: Imprenta Viuda de Luis Tasso, 1913.

ARANHA, B. F. T. Archivo do Amazonas I, 3 (1907): 55-109.

CASEMENT, R. The Amazon Journal of Roger Casement. Ed. Angus Mitchell. London: Anaconda Editions, 1997.

CREVEAUX, J. Voyages dans l'Amérique du Sur. Paris: Librairie Hachette et Cie., 1883.

CUNHA, E. da. Obra completa. Vol. I. Rio de Janeiro: José Aguilar Editora, 1966.

FRITZ, S. Journal of the Travels and Labours of Father Samuel Fritz in the River of the Amazons between 1686 and 1723. Trans. by Rev. Dr. George Edmundson. London: Hakluyt Society, 1922.

FOUCAULT, M. Power / Knowledge: Selected Interviews and Other Writings, 1971-1977. New York: Pantheon books, 1980.

HARDENBURG, W. E. The Putumayo: The Devil's Paradise. Travels in the Peruvian Amazon Region and an Account of the Atrocities Committed upon the Indians Therein. London: Adelphi Terrace / Leipsiz: Inselstrasse, 1912.

HERNDON, W. L. Exploration of the Valley of the Amazon, 1851-1852. Ed. Gary Kinder. New York: Grove Press, 2000.

HISPANO, C. De París al Amazonas - Las fieras del Putumayo. Paris: Librería Paul Ollendorf, 1912.

KOCH-GRÜNBERG, T. Dois anos entre os indígenas - viagens no noroeste do Brasil (1903/1905). Manaus: EDUA/FSDB, 2005.

MICHELENA Y ROJAS, F. Exploración oficial por la primera vez desde 
el norte de la América del Sur, bajada del Amazonas hasta el Atlántico. Bruselas: A Lacroix, Verboeckhoven y Ca., Impresores y Editores, 1867. OLARTE CAMACHO, V. Las crueldades en el Putumayo y en el Caquetá. Bogotá: Imprenta Eléctrica, 1910.

PATERNOSTER, S. The Lords of the Devil's Paradise. London: Stanley Paul \& Co., 1913.

PINELL, G. de. Un viaje por el Putumayo y el Amazonas - ensayo de navegación. Bogotá: Imprenta Nacional, 1924.

REY DE CASTRO, C., LARRABURE Y CORREA, C., ZUMAETA, P. \& ARANA, J. C. La defensa de los caucheros. Introd. de Andrew Gray. Iquitos: CETA/IWGIA, 2005.

REPORT AND SPECIAL REPORT OF THE SELECT COMMITTEE ON PUTUMAYO. Together with the Proceedings of the Committee, Minutes of Evidence and Appendices. Ordered by The House of Commons, $5^{\text {th }}$ June 1913. London, 1913.

RICE, H. Further Explorations in the North-West Amazon Basin. The Geographical Journal, Vol. 44, no. 2 (1914): 137-164.

RIVERO, J. Historia de las misiones de llos llanos de Casanare y los ríos Orinoco y Meta. Bogotá: Imprenta de Silvestre y Compañía, 1883.

ROCHA, J. Memorandum de viaje. Bogotá: Casa Editorial de El Mercurio, 1905.

SLAVERY IN PERU. Message from the President of the United States. Trasmitting Report of the Secretary of State, with Accompanying papers concerning the Alleged Existence of Slavery in Peru. Washington: House of Representatives, 1913.

SPIX, J. B. e MARTIUS, C. F. V. Viagem pelo Brasil (1817-1820). Vol. 3. São Paulo/Belo Horizonte: Edusp/Ed. Itatiaia, 1981.

TAUSSIG, M. "Culture of Terror-Space of Death. Roger Casement's Putumayo Report and the Explanation of Torture." Comparative Studies in Society and History, 26, 3 (July 1984): 467-497. 
THOMSON, N. The Putumayo Red Book. London: N. Thomson \& Co., 1913.

TRIANA, M. Por el sur de Colombia - Excursión pintoresca y científica al Putumayo. París: Garnier Hermanos, 1907. WALLACE, A. R. Viagens pelos Rios Amazonas e Negro. Trad. Eugênio Amado. São Paulo/Belo Horizonte: Edusp/Ed. Itatiaia, 1979.

WHIFFEN, T. The North-West Amazons. Notes of Some Months Spent among Cannibal Tribes. New York: Duffield And Company, 1915.

ZUMAETA, P. Las cuestiones del Putumayo, folleto 2. Barcelona: Imprenta Viuda de Luis Tasso, 1913. 